health care and other regulations. We are talking about the phrase "medical assistance" and "medical services".

Determined that the state and municipal institutions health care should be provided free of charge, the factual basis for it is seeking such assistance, the legal basis is article 49 of the Constitution of Ukraine and examined the decisions of the constitutional Court of Ukraine No. 1$29 / 98$ and No. 10-RP/2002. On these grounds, the state arises, the constitutional obligation to provide free medical care in public and private healthcare institutions.

Private institutions medical care is provided under the legal construction of "medical service", which is also in article 3 of the fundamentals of legislation on health care, namely: "the service of health care (medical service) - a service that is provided to a patient by a healthcare institution or a natural person - entrepreneur, which is registered and obtained in accordance with the law the license for implementation of economic activity on medical practice, and it is paid by the customer. Customer service in health care can be the state, relevant local authorities, legal entities and individuals, including the patient." Medical service is provided in the framework of civil or economic relations, on the basis of the agreement for the implementation of paid medical services.

Keywords: medical care, medical service, protection of human rights for health and life, trends in legal regulation, legislative support for human rights protection.

DOI: 10.33766/2524-0323.89.101-109

УДК 343.9:658:343.352

I. О. Христич, кандидат економічних наук, доцент, старший науковий співробітник

Науково-дослідного інституту вивчення проблем злочинності імені академіка

В. В. Сташиса НАПрН України (м. Харків, Україна) e-mail: krystych.inna@gmail.com (iDhttps://orcid.org/0000-0001-7494-7289

\title{
ПРОБЛЕМИ РОЗРОБКИ МЕТОДИКИ ВСТАНОВЛЕННЯ РЕАЛЬНИХ ОБСЯГІВ КОРУПЦІЇ В ПРИВАТНІЙ СФЕРІ УКРАЇНИ
}

У статті розглянуті проблеми, які виникають при розробці методики встановлення реальних обсягів корупщії в приватній сфері. Зазначено, що можна по-різному класифікувати методи, які використовуються в кримінології для отримання та опрацювання наукової інформації. На жаль, при дослідженні рівня корупшії можна застосовувати найчастіше лише такий соціологічний метод, як опитування. Зроблено висновок, що корупщія в нашій країні стала повсякденною практикою, тому розробка методики встановлення реальних обсягів корупіії в приватній сфері є одним з найважливіших інструментів дотримання вимог антикорупщійних законів України юридичними особами приватного права.

Ключові слова: корупція, приватна сфера, соціологічні методи, масові опитування, методика, перепис населення.

() Христич I. О., 2020 
Постановка проблеми. Корупщія, як соціально-економічна проблема, характерна для кожного суспільства. Рівень корупщії в кожній державі є різним та залежить від економічного, соціального, політичного, культурно-морального та психологічного розвитку суспільства в цілому та окремих громадян зокрема. Корупція, як стримувальний фактор соціально-економічного розвитку країни, є глобальною економічною проблемою з кінця XX ст. На жаль, нині Україна відповідно до рейтингу, опублікованого журналом «Transparency International», є однією з найбілыш корумпованих держав світу. За оцінками Світового банку, щорічний обсяг хабарів у світі сягає більше 1 трлн дол. США, що дорівнює обсягу ВВП таких країн, як Південна Корея, Мексика, Росія, Канада, Індія [1]. Безперечно, корупщія - надзвичайно актуальна проблема, розв'язання якої необхідне для багатьох країн, незалежно від рівня розвитку. Повною мірою це стосується України, високий рівень корумпованості котрої визнано їїполітичним керівнищтвом, законодавчими органами, вітчизняними та зарубіжними аналітиками, міжнародними інституціями.

За даними досліджень, саме корупщія є однією з причин, що призвела до масових протестів в Україні наприкінщі 2013 р. - на початку 2014 р. Згідно з результатами дослідження «Барометра Світової Корупщії (Global Corruption Barometer), проведеного міжнародною організацією Transparency International у 2013 р., 36 \% українщів були готові вийти на вулищі протестувати проти корупщіі. За результатами дослідження громадської думки, проведеного Міжнародною фундацією виборчих систем (IFES) наприкінщі 2013 р., корупщія вже входила до переліку найбілыших проблем населення і викликала занепокоєння у 47 \% громадян [2, с. 70 - 71].

На жаль, 2019 р. охарактеризувався лише незначним зменшенням рівня корупції в Україні. У 2019 р. вона втратила два бали в рейтингу сприйняття корупщії в порівнянні з 2018 р. і повернулася на рівень 2017 р., посівши 126-те місце зі 180 [3]. Отже, пильної уваги вимагає розробка методики оцінки рівня корупщії в приватній сфері, тому що $з$ нею стикається пересічний громадянин країни практично щоденно. Тим паче вважається, що рівень корупщії становить 4-10 \% обороту компанії, а частина компаній втрачає бізнес через корупщійні дії конкурентів [4, с. 6].

Стаття підготовлена відповідно до планів проведення наукових досліджень НДІВПЗ НАПрН України за фундаментальною темою «Кримінологічні проблеми запобігання корупщії у приватній сфері», що затверджена постановою Президіі НАПрН України від 21 червня 2016 р. № 97/7 та постановою № 6/5 Вченої ради Інституту від 28 грудня 2016 р. (Номер державної реєстрації 0117U000280).

Аналіз останніх досліджень і публікацій. Багатоаспектні проблеми вдосконалення статистичного обліку корупційних правопорушень порушені в працях вітчизняних учених та представників ближнього та далекого зарубіжжя. Це дослідження М. І. Бажанова, Ю. В. Бауліна, В. І. Борисова, В. В. Голіни, Б. М.Головкіна, А. П. Закалюка, В. С. Зеленецького, О. Г. Кальмана, Т. В. Корнякової, О. М. Литвинова, М. В. Романова, В. В. Сташиса, Л. О. Шевченко, Л. Шелли та інших учених. Проте, на жаль, у білышості публікацій проблемі встановлення реальних обсягів корупщії у приватній сфері не приділяється належної уваги, особливо це стосується розробки методики їх встановлення, а також тим проблемам, які виникають при цьому. 
Формулювання цілей. Метою статті є аналіз стану розробки методик встановлення обсягів корупщії у приватній сфері України, особливо проблем, які виникають при їх розробці.

Виклад основного матеріалу. Найчастіше корупщію поділяють на побутову (пов'язану з повсякденним життям громадян), бюрократичну або адміністративну (що виникає при взаємодії громадян, підприємщів із чиновниками нижчої чи середньої ланки), політичну (корупщійна поведінка осіб, які приймають політичні рішення) $[5$, с. 353].

Корупщійні прояви за сферами суспільних відносин, які мають високі корупційні ризики, розподіляють на приватну та публічну сфери. Приватна сфера - це сукупність суспільних відносин, яка складається серед окремих осіб (юридичних або фізичних) з приводу реалізації приватних інтересів [6, с. 29].

У дослідженнях Міжнародного валютного фонду підтверджено, що зростання рівня корупщії на одну одиницю (за шкалою від 0 до 10) призводить до зниження реального збільшення ВВП на одну особу на 0,3-1,8 \% [7]. Більшість дослідників корупщії схильні вважати, що корупщія зменшує доходи в суспільстві, навіть перерозподіляє ї на користь окремих верств населення і гальмує соціально-економічне зростання [8], про що свідчить виявлення впливу індексу сприйняття корупщії внутрішнього валового продукту на одну особу (у найменш корумпованих країнах він становить 9-10 i, навпаки, у країнах з високим рівнем корупщії - менше 3). При викоріненні корупщії в краӥні зростає показник ВВП на одну особу.

Проблема корупщії в приватному секторі враховується також у визначенні, що подається Міждисциплінарною групою з корупщії Ради Європи: «Корупція - це хабарництво та будь-яка інша винагорода особі, якій доручено виконання певних обов' язків у державному або приватному секторі, що веде до порушень зобов'язань, покладених на неї за статусом державної посадової особи, приватного співробітника, незалежного агента, або іншого роду відносин з метою отримати будь-які незаконні вигоди для себе та інших» [9].

Методологія науки - це система основних поглядів, принципів розуміння оточуючого Світу, що є базовими для наукового пізнання. Згідно $з$ нею визначаються напрямки наукового пошуку, пояснюються виявлені закономірності, здійснюються прогнози розвитку явищ. Тому положення наукової методології для кримінологічних досліджень мають принципове значення.

Зараз у вітчизняній кримінології базовою є методологія теорії діалектики. Її основним постулатом є твердження про суцільний взаємовплив та взаємодію об'єктів Світу в різний спосіб та різними формами [5, с. 26]. Це ще раз наголошує тезу, що всі суспільні явища видозмінюються, і тому їх дуже складно вимірювати та оцінювати.

Різні вчені по-різному класифікують методи, які використовуються в кримінології для отримання та опрацювання наукової інформації. Найбільш уживаним $е$ розподіл на загальнонаукові та галузеві. Загальнонаукові - це засоби отримання інформації, застосування яких є загальним для багатьох гуманітарних і технічних наук (описування, аналіз, експеримент). До галузевих методів відносять інтерв'ю, дослідження документів, тобто методи тільки гуманітарних наук. Кримінологія використовує також методи статистичні, соціологічні, психологічні, економічні, зокрема, 
монетарний метод, який визначає масштаби тіньової економіки через обсяги позабанківського обігу готівкових коштів.

Під час проведення кримінологічних досліджень найчастіше застосовуються такі методи: соціологічний, статистичний, психологічний, системний аналіз. Соціологічний (анкетування, інтерв'ювання, вивчення документів, експеримент, експертних оцінок тощо), який дає змогу глибше пізнати соціальний аспект явищ, процес їх детермінащії, зібрати емпіричний матеріал, що характеризує як стан і динаміку злочинності в цілому, так і окремі ії види, предметно з' ясувати чинники злочинності та розробити заходищодо запобігання. Статистичний метод дозволяє дослідити масив злочинів і за допомогою отриманих показників встановити закономірності та взаємозалежності їх розвитку, перейти від випадкового й одиничного до стійкого і закономірного, побачити якісні ознаки досліджуваного явища. Історико-порівняльний метод допомагає вивчити тенденщії розвитку злочинності, зміни ї̈ стану і структури за той чи інший період, без чого неможливо розробити ефективні заходи щодо запобіганням. Психологічні методи (наприклад, соціометрії, тестування) слугують для вивчення співвідношення об'єктивного і суб'єктивного в поведінщі злочинщя, процесу формування антисоціальних властивостей особи, виникнення злочинного наміру, мотивації вчинення кримінального правопорушення тощо. Системний аналіз дає змогу розглядати злочинність як феномен, для якого характерні певні зв'язки між складовими елементами, з одного боку, а з другого - між злочинністю та іншими соціальними явищами і процесами, які впливають на неї. Результати дослідження, отримані під час використання того чи іншого методу, потрібно належно оформити та довести до зацікавлених користувачів [10, с. 28- 29].

Зрозуміло, що під час проведення кримінологічних досліджень найчастіше використовуються соціологічні методи, особливо в нашій країні. Тим паче складно встановити реальний обсяг корупщії в нашій країні, особливо в приватній сфері.

На жаль, загального опитування в масштабі всього суспільства у нас ніколи не проводилося. Перепис населення був проведений останній раз у 2001 р. Розрахунок демографів і соціологів щодо встановлення соціального здоров' я населення та його структури, який, вважалося, отримуємо під час перепису населення 2020 р., не справдився. Чинна влада замінила його реєстровим, або комбінованим, і встановила, що на 1 грудня 2019 р. нас 37 млн. 289 тис. осіб, зауваживши при цьому, що похибка склала, за думкою тих, хто проводив цю оцінку чисельності населення, $\pm 2,86$ \% від визначеної величини, і це дасть змогу заощадити 2-3 млрд грн. до бюджету 2020 року.

Три впливові соціологічні служби - Фонд «Демократичні ініціативи» імені Ілька Кучеріва, Центр Разумкова та Київський міжнародний інститут соціології- у грудні 2019 року провели дослідження (опитування) громадян України. Зокрема, більшість населення (68,9 \%) вважає, що розвитку країни найбілыше заважає корупція. Проте з усіх реформ відносно успішними було визнано лише антикорупщійну реформу (10\%), реформу децентралізації (10 \%), реформу охорони здоров' я та армії (по 9 \% відповідно), земельну реформу (8 \%). Жодної успішної реформи не назвали $51 \%$ опитуваних (торік - 41 \%) [11].

Саме із подоланням корупщії в Україні 54 \% керівників компаній-членів Американської торговельної палати пов' язують покращення бізнесклімату та зростання 
прямих іноземних інвестищій в економіку. Такі дані були представлені 29 жовтня 2019 р. на Інвестищійному форумі «RE:THINK Invest in Ukraine» як результати опитування топменеджерів зі 110 компаній-членів Американської торговельної палати (АСС) щодо бізнесклімату в Україні [12].

Ще у 2014 р., на думку Transparency International Україна, головними рекомендаціями для приватного сектору в Україні, з урахуванням названих вище міжнародних стандартів та законодавства України, могли б бути такі: лідерство; антикорупщійні програми; внутрішній контроль та аудит; зовнішній контроль [13, с. 14].

Лідерство. У компанії повинна бути явно виражена воля власника та керівнищтва компанії щодо заборони будь-яких форм хабарнищтва й іншої недоброчесної поведінки. Така політика має бути доведена до відома кожного працівника компанії, а власники та менеджмент компанії мусять неухильно ії дотримуватись та власним прикладом впроваджувати в життя.

Антикорупційні програми. Компанія має здійснити аналіз можливих корупціогенних ризиків, інших чинників, пов' язаних із спроможністю компанії запобігати та протидіяти корупщії, провести консультації із працівниками, професійними спілками та на їх основі підготувати програму запобігання корупщії.

Програма повинна відбивати політику компанії, правила та процедури щодо запобігання та протидії корупщії з урахуванням специфіки діяльності компанії, відносин із іншими компаніями, кількості працівників та інших особливостей компанії. Одними із найбілыш важливих елементів програми мають бути система аналізу ризиків корупщії, кодекс поведінки працівників компанії та механізми запобігання, виявлення та вирішення конфлікту інтересів.

Один із керівників компанії повинен бути визначений відповідальним за імплементацію антикорупщійної програми, іï моніторинг, перегляд, а також застосування санкцій. Перегляд програми має здійснюватися на регулярній основі, з урахуванням аналізу стану виконання ії заходів.

Принципи запобігання корупщї, визначені програмою, повинні застосовуватись у всіх видах діяльності компанії та їі відносинах із державою, юридичними та фізичними особами. Компанія має забезпечити публічність щодо змісту програми та бути зацікавленою у зовнішніх комунікаціях щодо виконання програми (наприклад, повідомлення інших компаній щодо можливих фактів корупщійних діянь).

Відносини, пов' язані із добором, кар'єрним просуванням, ощінкою якості виконання своїх обов' язків персоналом повинні також регулюватися з урахуванням принщипів, визначених антикорупщійною програмою компанії.

Компанії повинні забезпечити періодичне проходження тренінгів як для керівнищтва, так і для іншого персоналу з питань, пов' язаних із антикорупційною політикою компанії. Крім того, мають бути створені механізми для надання порад для персоналу щодо правильної поведінки в умовах потенщійного конфлікту інтересів чи порушення правил щодо запобігання корупщії.

Особи, які відмовляються від виконання вказівок чи доручень щодо дачі хабара чи інших видів корупщійної поведінки, не можуть бути покарані за таку відмову та повинні мати можливість анонімного повідомлення про ці факти, зокрема через внутрішні механізми компанії. 
Доброчесне повідомлення по підозру у вчиненні корупщійного діяння не може ні прямо, ні опосередковано тягнути за собою притягнення особи до будь-якого виду відповідальності.

Внутрішній контроль та аудит. Компанії повинні здійснювати належний внутрішній контроль за виконанням заходів, передбачених антикорупційною програмою. Крім того, у компаніях має бути власний підрозділ аудиту (там, де це дозволяе чисельність працівників), який на основі власного плану здійснює регулярні аудиторські перевірки.

Зовнішній контроль. Керівництво компанії повинно розглянути можливість щодо можливості зовнішньої перевірки імплементації антикорупщійної політики компанії та можливого оприлюднення результатів такої перевірки.

3 листопада 2013 р. по лютий 2014 р. дослідники Міжнародного агентства маркетингових досліджень «Ппсос» провели 2719 інтерв'ю рідною мовою для осіб, що приймають рішення, у низці великих компаній 59-ти країн світу. Було опитано 2658 респондентів. Дане опитування показало, що перші особи компаній менш, ніж підлеглі, схильні відвідувати тренінги з питань боротьби з хабарництвом / корупщією (38 \%), або брати участь в оцінщі ризиків у рамках боротьби з хабарництвом / корупщією (30\%).Цетривожний сигнал, враховуючи, що керівники, схоже, регулярно стикаються з обставинами, що загрожують їх чесній репутації. 21 \% топменеджерів заявили, що колись стикалися з пропозицією дати хабар у порівнянні 310 \% всіх опитаних управлінців. Турбує те, що 11 \% керівників вищої ланки, які диктують модель поведінки, вважають, що спотворення фінансових показників можна виправдати, якщо це допомагає бізнесу вижити в умовах економічного спаду (у порівнянні 36 \% всіх інших респондентів) [14].

На початку 2019 року Transparency International Ukraine надала 12 рекомендацій, які б могли покращити показники України в СРІ. Станом на кінець року було виконано або частково виконано лише 6 із них, і ті в останньому кварталі 2019-го.

Висновки. На жаль, можна констатувати, що практично при спробі встановити реальний обсяг корупщійних діянь, особливо в Україні, спрацьовує соціологічний метод - опитування, але він може давати позитивні результати лише тоді, коли застосовується систематично й з тим же самим контингентом, щоб реально можна було оцінити зміну точку зору населення.

Корупщія в нашій країні стала повсякденною практикою, а антикорупщійні заходи на підприємствах застосовуються відносно не тривалий час і в більшості компаній носять декларативний характер. Тому розробка методики реальних обсягів корупції у приватній сфері є одним з найважливіших інструментів реалізації стратегіїіх мінімізації та дотримання юридичними особами приватного права вимог антикорупщійних законів держави. Проблеми, з якими стикаються при ї̈ розробці, це відсутність реальних даних щодо стану корупщії в Украӥні.

Причому необхідно враховувати, що протидія корупції є також заключним серед 10-ти принципів Глобального договору ООН - добровільної ініціативи, яку підтримали понад 8 тисяч компаній та організацій у світі та понад 190 в Україні. Долучившись до Глобального договору, компанії беруть на себе зобов'язанння створювати та підтримувати етичні засади корпоративної культури як на стратегічному, так і на операційному рівнях. 


\section{Використані джерела:}

1. World bank. Costs of corruption. URL: http:// search.worldbank.org/all?qterm=briber y\&os=10. (дата звернення 10.02. 2020).

2. Корупщійна злочинність: витоки, сучасний стан, стратегія протидії: монографія / Т. В. Корнякова, О. Л. Соколенко, І. Г. Алексеєнко та ін..; за заг. ред. Т. В. Корнякової. Дніпpo: Лipa, 2017. 276 c.

3. Corruption Perceptions Index 2019 - Transparency International. URL: www. Transparency.org > срі2019 (дата звернення 10.02. 2020)

4. Аналітична довідка «Боротьба з корупщією. Роль бізнесу в Україні». К.: ТОВ «Фарбований лист», 2011.51 с.

5. Кримінологія: підручник /В. В. Голіна, Б. М. Головкін, М. Ю. Валуйська та ін.; за ред. В. В. Голіни, Б. М. Головкіна. Харків: Право, 2014. 512с.

6. Романов М. В. Основні засади запобігання корупщії. Харків: ТОВ «Видавництво «Права людини»», 2017.176 c. 1.shtml.

7. Global Corruption Report 2011. URL: http:// www.globalcorruptionreport.org/gcr201

8. Barro R. J. Determinants of Economic Growth: A Cross-Country Empirical Study / R. J. Barro. - Cambridge, MA: MIT Press, 1997.

9. Civil Law Convention on Corruption (ETS No 174) // Combating Corruption. Anticorruption instruments of the Council of Europe. 2007. Vol. 3. P. 31-40.

10. Богатирьов І. Г. Кримінологія: підручник / заг. ред. І. Г. Богатирьова, В. В. Топчія. Київ: ВД Дакор, 2018. 352 с.

11. Реформи в Україні: громадська думка населення. URL: https:// dif.org.ua/ article/reformi-v-ukraini-gromadska-dumka-naselennya-2019 (дата звернення: 08.02.2020).

12. Інвестиційний потенціал України - результати опитування Американської торговельної палати (ACC) URL: http:/ / chamber.ua/uk/Media/News/12789 (дата звернення: 08.02.2020).

13. Відповідальність бізнесу за корупщію. Методичні рекомендації щодо застосування положень Закону України «Про внесення змін до деяких законодавчих актів України щодо виконання Плану дій щодо лібералізації Європейським Союзом візового режиму для України стосовно відповідальності юридичних осіб». Київ. 2014. 65 с.

14. Зростання корупшії в світі змушує бізнес боротися, щоб вижити. URL: http:// csr- ua.info/csr- ukraine/news/ey- \%D0\%B7\%D1\%80\%D0\%BE\%D1\%81\%D1\%82\%D0\%B0\% D0\%BD\%D0\%BD\%D1\%8F- \%D0\%BA\%D0\%BE\%D1\%80\%D1\%83\%D0\%BF\%D1\%86\%D1\%96 \%D1\%97- \%D1\%83- \%D1\%81\%D0\%B2\%D1\%96\%D1\%82\%D1\%96- \%D0\%B7\%D0\%BC\%D1\%8 3\%D1\%88\%D1\%83\%D1\%94-\%D0\%B1\%D1\%96/(дата звернення: 08.02.2020).

\section{References:}

1. World bank. Costs of corruption. URL: http://search.worldbank.org/all?qterm=briber $y \& o s=10$.

2. Korniakova, T. V., Sokolenko, O. L., Alekseienko, I. H. et al. (2017). Koruptsiina zlochynnist: vytoky, suchasnyi stan, stratehiia protydii: monohrafiia. T. V. Korniakova (Ed.). Dnipro: Lira. [in Ukrainian].

3. Corruption Perceptions Index 2019 - Transparency International. URL: www. Transparency.org > cpi2019. [in English].

4. Analitychna dovidka «Borotba z koruptsiieiu. Rol biznesu v Ukraini». (2011). Kyiv: TOV «Farbovanyi lyst». [in Ukrainian]. 
5. Holina, V. V., Holovkin, B. M., Valuiska, M. Yu. etal. (2014). Kryminolohiia. V. V. Holina, B. M. Holovkin (Eds.). Kharkiv: Pravo. [in Ukrainian].

6. Romanov, M. V. (2017). Osnovni zasady zapobihannia koruptsii. Kharkiv: TOV «Vydavnytstvo «Prava liudyny»». [in Ukrainian].

7. Global Corruption Report 2011. URL: http://www.globalcorruptionreport.org/gcr201 1.shtml. [in English].

8. Barro, R. J. (1997). Determinants of Economic Growth: A Cross-Country Empirical Study / R. J. Barro. Cambridge, MA: MIT Press. [in English].

9. Civil Law Convention on Corruption (2007). Combating Corruption. Anti-corruption instruments of the Council of Europe, (ETS No. 174), Vol.3, 31-40. [in English].

10. Bohatyrov, I. H. (2018). Kryminolohiia. I. H. Bohatyrov, V. V. Topchii (Eds.). Kyiv: VD Dakor. [in Ukrainian].

11. Reformy v Ukraini: hromadska dumka naselennia. N. d. N. p. URL:https:// dif.org.ua/article/reformi- v- ukraini- gromadska- dumka- naselennya- 2019 [in Ukrainian].

12. Investytsiinyi potentsial Ukrainy - rezultaty opytuvannia Amerykanskoi torhovelnoi palaty (ACC) N. d. N. p. URL: http://chamber.ua/uk/Media/News/12789 [in Ukrainian].

13. Vidpovidalnist biznesu za koruptsiiu: Metodychni rekomendatsii shchodo zastosuvannia polozhen Zakonu Ukrainy «Pro vnesennia zmin do deiakykh zakonodavchykh aktiv Ukrainy shchodo vykonannia Planu dii shchodo liberalizatsii Yevropeiskym Soiuzom vizovoho rezhymu dlia Ukrainy stosovno vidpovidalnosti yurydychnykh osib» (2014). Kyiv. [in Ukrainian].

14. Zrostannia koruptsii v sviti zmushuie biznes borotysia, shchob vyzhyty. URL: http:// csr- ua.info/csr- ukraine/news/ey- \%D0\%B7\%D1\%80\%D0\%BE\%D1\%81\%D1\%82\%D0\%B0\% D0\%BD\%D0\%BD\%D1\%8F- \%D0\%BA\%D0\%BE\%D1\%80\%D1\%83\%D0\%BF\%D1\%86\%D1\%96 \%D1\%97- \%D1\%83- \%D1\%81\%D0\%B2\%D1\%96\%D1\%82\%D1\%96 \%D0\%B7\%D0\%BC\%D1\%8 3\%D1\%88\%D1\%83\%D1\%94- \%D0\%B1\%D1\%96/ [in Ukrainian].

Стаття надіӥила до редколегії 15.02.2020

Христич И. А., кандидат экономических наук, доцент, старший научный сотрудник отдела криминологических исследований научно-исследовательского института изучения проблем преступности имени академика В. В. Сташиса

НАПрН Украины (г. Харьков, Украина)

\section{ПРОБЛЕМЫ РАЗРАБОТКИ МЕТОДИКИ УСТАНОВЛЕНИЯ РЕАЛЬНЫХ ОБЪЕМОВ КОРРУПЦИИ В ЧАСТНОЙ СФЕРЕ УКРАИНЫ}

В статъе рассмотрены проблемы, возникающие при разработке методики установления реальных объемов коррупции в частной сфере. Подчеркнуто, что можно поразному классифицировать методы, используемые в криминологии для получения научной информации. К сожалению, при исследовании уровня коррупции наиболее часто используется только такой социологический метод, как опрос. Вывод: коррупщия в нашей 
стране стала ежедневной практикой. Поэтому разработка методики установления реальных объемов коррупци в частной сфере является одним з наиболее важных инструментов соблюдения юридическими лицами частного права требований антикоррупционных законов страны.

Ключевые слова: коррупщия, частная сфера, социологические методы, массовый опрос, методика, перепись населения.

Khrystych I.,

$\mathrm{Ph} . \mathrm{D}$ in Economics,

Senior Scientific researcher

of Department of Criminological research of Academician Stashis Scientific Research Institute for the Study of Crime Problems of the National Academy of Law Sciences

(Kharkiv, Ukraine)

\section{PROBLEMS OF DEVELOPMENT OF METHODOLOGY FOR ESTABLISHMENT OF REAL CORRUPTION VOLUMES IN THE PRIVATE SPHERE OF UKRAINE}

The article, prepared in accordance with the plans of scientific research of the Scientific Research Institute for the Study of Crime Problems of the National Academy of Legal Sciences of Ukraine on the fundamental theme "Criminological problems of preventing corruption in the private sphere", considers the problems of developing a methodology for establishing real volumes of corruption in the private sphere.

It is analyzed that corruption is most often divided into household (connected with the daily life of citizens), bureaucratic or administrative ones (arising from interaction of citizens, entrepreneurs with lower or middle level officials), political one (corruption behavior of political decision makers). Corruption manifestations in the areas of public relations that have high corruption risks are divided into private and public spheres. The private sphere is a set of social relations that is formed among individuals (legal or natural) about the realization of private interests.

It is emphasized that the methods used in criminology to obtain and treat scientific information can be classified differently. Unfortunately, when investigating the level of corruption, it is often possible to use only such sociological method as the poll.

The results of the poll, conducted by the Ilko Kucheriv Democratic Initiatives Fund, the Razumkov Center and the Kiev International Institute of Sociology in December 2019, have been analyzed. The majority $(68,9 \%)$ of the polls believe that corruption is most hindering the country's development. At the same time, only $10 \%$ consider the anti-corruption reform successful.

It is concluded that corruption in our country has become a common practice. Therefore, the development of a methodology for real volumes of corruption in the private sphere is one of the most important tools for implementing a strategy for minimizing them and for the private law legal entities to comply with the requirements of the anti-corruption laws of the state. The problems encountered in its development are the lack of real data on the state of corruption in Ukraine.

Keywords: corruption, private sphere, sociological methods, mass surveys, methodology, population census. 